\title{
Látássérült személyek mentális lexikona a szóasszociációk tükrében*
}

1. Bevezetés. A jelen kutatás a látássérültek beszédfolyamatainak pontosabb megismerésére ad lehetőséget. A téma jelentőségét az adhatja, hogy magyar nyelven alig létezik a látássérültek közösségét nyelvészeti célból megközelítő kutatási eredmény, holott a nemzetközi tudományos életben a közelmúltban és jelenleg is számos kutatási projektum (többek között pl. KANJLIA et al. 2016; BOTTINI et al. 2015; SCHINAZI et al. 2016; GELD 2014; HUGHDAHL et al. 2004; LASSONDE et al. 2004) tevékenysége irányul ennek a közösségnek a mélyebb megismerésére. Ezek jelentős része idegtani, neurológiai kiindulópontú vizsgálat (pl. DIETRICH et al. 2015; BEDNY et al. 2012), más részük nyelvészeti, amelyek főként a hallott szöveg percepciójának kérdéskörét vizsgálják (pl. HERTRICH et al. 2013). Ezeknek a vizsgálatoknak közös jellemzőjük, hogy arra keresik a választ, egy érzékszerv kiesése milyen hatással van az agytevékenységre, milyen mértékü lehet az agyi flexibilitás, más érzékszervek mennyire képesek átvenni a hiányzó érzékelési mód szerepét, valamint a nyelvi tevékenységet hogyan határozza meg más érzékterületek müködésének felerősödése. A jelen kutatás is ebbe a párbeszédbe szeretne bekapcsolódni azáltal, hogy a látássérült személyek mentális lexikonának müködésére vonatkozó pontosabb leíráshoz kíván hozzájárulni.

1.1. A mentális lexikon múködése és a lexikális előhívás. A mentális lexikon az az agyi tároló rendszer, amelyben a nyelv és a beszéd egységeit, szabályait tároljuk. Három részét szokták elkülöníteni: 1. aktív szókincs, 2. passzív szókincs, illetve 3. éppen aktivált szókincs (GósY 2005: 193-194). Más forrásokban az aktív és passziv szókincs elnevezések helyett az expresszív, illetve receptiv kifejezéseket alkalmazzák (LUKÁCs 2014: 539). Az aktív szókincs azoknak a nyelvi elemeknek az összessége, amelyeket az egyén gyakran használ, ezzel szemben a passzív szókincsbe azok a nyelvi és beszédjelek tartoznak, amelyek ritkábbak a beszéd során. Az éppen aktivált szókincs azokat az elemeket jelenti, amelyeket az egyén adott beszédhelyzetben aktivál (Gósy 2005: 194).

A morfológiailag komplex szavak tárolását tekintve kétféle elméletet tartunk számon. Az ún. holisztikus (egészleges) tárolás szerint a hozzáférés gyors, nagy tárhelyet igényel a mentális lexikonban, az új alakok létrehozása analógiás, hasonlósági úton mehet végbe. Az analitikus (elemzö) megközelítés azt állítja, hogy a szavak töve van tárolva, és az azokat alakító nyelvtani szabályok. A legtöbb mai modell a kettő párhuzamos müködését feltételezi (LUKÁCS-PLÉH-KAS-THUMA 2014: 222-227).

3-4 éves korra valószínűsíthetően kialakulnak az alapvető nyelvspecifikus fonológiai reprezentációk, a szemantikai alapú hálózat szerkezetileg kiépül, a szavak tárolása a felnőtt nyelvi rendszer szerint történik, és a lexikális hozzáférési módok ekkorra már valószínűleg megközelítik a felnőttekét (GósY-KovÁCS

* A szerző ezúton szeretné megköszönni tanulmánya lektorainak értékes tartalmi, illetve formai javaslatait, amellyel hozzájárultak a tanulmány végleges változatának kialakításához.

Magyar Nyelv 112. 2016: 419-432. DOI: 10.18349/MagyarNyelv.2016.4.419 
2001: 331). Egyes kutatási eredmények arra mutatnak, hogy kezdetben a szintaktikai elemzéseken van a hangsúly, de később ezt a szerepet átveszik a szemantikai elemzések, felnőttkorban pedig föként ezek irányítják e mentális folyamatokat (LUKÁCS 2014: 530-531).

Az adott nyelvi és beszédjel lexikonban történő keresését és megtalálását lexikális hozzáférésnek nevezzük (GósY 2005: 195). Az előhívást befolyásolja az ún. Priming-hatás, vagyis az, hogy az előhívás előtt milyen szavak szerepeltek az elhangzó beszédben, valamint további befolyásoló tényezők a szógyakoriság, a szóhossz, a szavak nyelvtani kategóriája is (LUKÁCS-PLÉH-KAS-THUMA 2014: 195-205).

1.2. A szóasszociációs vizsgálatok. A mentális lexikon vizsgálatának sokak által alkalmazott módszere a szóasszociációs vizsgálatoknak a lefolytatása, amelyeknek a segítségével azt mérjük, hogy az adott szituációban kiejtett hívószavakról a kísérleti személynek mi jut eszébe. A szóasszociációs vizsgálatoknak többféle típusuk van, melyek a következőek: a) szabad szóasszociáció: az adatközlőnek előre meghatározott hívószóra kell előhívnia az első szót, ami eszébe jut; b) szükített szóasszociáció: az adatközlőtől a megadott hívószóra meghatározott kategóriájú választ várnak; c) nyitott teszt: egy meghatározott jelentéskategórián belül kell annyi szót előhívni, amennyi eszébe jut a vizsgált személynek (GósY 2005: 203-204). Egy következő típus az ún. betüfluencia-vizsgálat, amelynek során az előhívandó szavak első betüje meg van adva, és ezt figyelembe véve kell szavakat aktiválni (LUKÁCS-PLÉH-KAS-THUMA 2014: 173-176).

A válaszok alakulását befolyásolja a kísérletvezető személye, az adatközlő kora, neme, képzettsége, nyelvismeretének szintje, az adott kultúrkörhöz való tartozása, intelligenciája és verbális képessége, érdeklődési köre, valamint a szülők végzettsége is (KovÁCs 2013: 36-37). Egyes kutatások szerint legkönnyebben a közvetlen tapasztalást, a perceptuális evidenciát, legkevésbé pedig a szociokulturális sajátosságokat tükröző válaszokat hívják elő az adatközlők (LENGYEL 2012: 83-94).

A hívószóra adott válaszok egy lehetséges besorolása: 1. fonetikai (hangzási) összefüggés; 2. szerkezeti összefüggés (szóképzés, szóösszetétel, szószerkezet); 3. szemantikai összefüggés. Az utóbbi kategórián belül meg lehet különböztetni mellérendelö (lepke - szúnyog - méhecske), ellentétes (sovány - kövér), komplementer (apa - anya), rész-egész (pálmafa - kókusz) és alá-fölé rendelési viszonyokat (Duna - folyó) is (NEUBERGER 2008). Az asszociációk között megkülönböztetünk szófajmegőrző és szófajváltó szópárokat is. Szófajmegőrzésről beszélünk, ha a válaszszó szófaja megegyezik a hívószóéval, szófajváltásról pedig akkor, ha a két szó szófaja eltér egymástól.

1.3. A látássérültek. A jelen kutatás célcsoportját a látássérültek közössége alkotja, így szükségesnek tartom a látássérüléssel rendelkezők populációjának a bemutatását a legfontosabb jellemzők kiemelésével.

A látás a legfontosabb érzékszervünk, amelynek nagy szerepe van a tanulásban és a tapasztalatszerzésben (PARASZKAY 2007: 9-13). A látássérültek kb. 80\%-ának van valamilyen látásmaradványa, ezért használjuk inkább a látássérült kifejezést, és nem a vak-ot; utóbbi kifejezés emellett az idők során pejoratívvá is vált a magyar nyelvben, hasonlóan a süket melléknév jelentésváltozásához. A veleszületetten látássérült személyek aránya csökken, de az időskori látássérülés aránya nő; Ma- 
gyarországon a látássérültek legnagyobb része az idősek közül kerül ki (PAJOR 2010: 11-20).

„Látássérültnek tatjuk azokat, akiknek látásélessége két szemükön együtt korrigáltan (szemüveggel vagy bármilyen látásjavító eszközzel) a teljes látáshoz $(1,0)$ viszonyítottan 0-0,33 közötti” (CZIBERE-SZILÁGYI szerk. 2006: 7). A látásteljesítmény, látásélesség (vizus) minősége alapján megkülönböztetünk vakokat, aliglátókat és gyengénlátókat. A vakok vizusa 0 , még fényt sem érzékelnek. Az aliglátók vizusa 0,01-0,09 (1-9\%) közé esik, alcsoportjaik: fényérzékelők, nagytárgylátók, ujjolvasók. A gyengénlátók látásélessége a 0,1-0,3 közötti tartományba esik, vagyis ők állnak legközelebb a látó többséghez. Náluk a látás a vezető érzékelési csatorna, oktatásukban is fel lehet használni ezt az érzékelési módot. A látássérülés keletkezési ideje szerint megkülönböztetünk veleszületett és szerzett sérülést. A látássérülés prognózisa szerint pedig létezik progrediáló, azaz romló, valamint stacionér (megállapodott) kórfolyamat (CZIBERE-SZILÁGYI szerk. 2006: 1-8).

A látássérültek esetében a látás hiányából vagy részlegességéből származó hátrányt más érzékterületek müködése ellensúlyozza, vagyis a hallás, szaglás, ízlelés, tapintás útján szerezhető információk válnak hangsúlyossá. A vakoknál az olyan elemek, melyek csak látás útján ragadhatók meg, mint a szín- és fényjelenségek, érzékletes tartalom nélkülivé válnak. A látás és tapintás útján észlelhető azon jelenségeknek (mélység és távolság), amelyekben a vizuális tapasztalat dominál, a vakok számára van érzékletes tartalmuk, de nem azonos a látókéval. A látássérült érzékleti tapasztalata sokszor teljesen vagy részlegesen hiányos, ilyen a monumentalitásnak az érzékelése vagy a festői alkotások befogadása (CZIBERE-SZILÁGYI szerk. 2006: 14).

A vakok az érzékelés során mindig valamely résztulajdonságot figyelnek, a látókkal ellentétben nem elsősorban az alakot, hanem olyan tulajdonságot, amelyet a látók viszont nem tartanak lényegesnek, vagyis a valóságnak más szegmenseit emelik ki a tájékozódás során. A tér megragadása és tárolása elsősorban látás útján történik, a látás a tárgyak relációiról és távolságáról is tájékoztat. A tér a vakok számára nem tartály, hanem különböző útvonalak hálózata, amelyben vannak kiemelt viszonyítási pontjaik. Átszerveződés, szerkezeti változások következnek be a térérzékelésben, a formaészlelésben és a fogalmak belső struktúrája terén is. (PÁlHEGYI 1981: 22-36.)

1.4. A kutatás célja, hipotézisei. A jelen kutatás célja az volt, hogy képet adjon a látássérültek mentális lexikonáról és arról, hogy milyen reprezentációkat tárolhatnak az elméjükben az olyan jelenségekről, amelyeket nem látnak. A legfontosabb kutatási kérdés az volt, hogy mást hívnak-e elő akkor, ha olyan hívószóra kell asszociálniuk, amelynek a tartalmát képesek érzékszerveikkel befogadni (hallás, tapintás, szaglás, ízlelés által befogadható jelenségeknek megfelelő szavak szemantikai köre), mint akkor, ha olyan hívószóra kell reagálniuk, amely egy olyan valóságdarabot jelöl, amelyet nem tudnak érzékelni, mivel azt csak a látással lehetne befogadni.

A vizsgálat során megfogalmazott hipotézisek a következők voltak: 1. A látássérültek mentális lexikona más reprezentációkat tárol a látókhoz képest azon nyelvi jelölők esetében, amelyekhez a nyelven kívüli valóságban olyan elem tar- 
tozik, amelyet látás vagy főként látás útján lehet észlelni. 2. A látássérültek asszociációi azon hívószavak esetében, amelyeknek a nyelven kívüli valóságban létező megfelelője nem a látás, hanem más érzékszerv útján fogadható be elsődlegesen, nagyobb hasonlóságot mutatnak a látók asszociációihoz, mint a látásra épülő hívószavak asszociátumai.

2. Anyag, módszer és kísérleti személyek. A kutatás kísérleti úton történt, a kísérlethez kialakított feladatokat élőszóban kellett megoldani. A feladatok megoldásáról hangfelvételek készültek, amelyeket hangszigetelt süketszobában rögzítettem diktafonra. A feladatok megoldásainak nyelvi anyagát lejegyeztem, és táblázatkezelő program segítségével végeztem rajtuk el a számításokat.

A kísérletben egy 10 látássérült (vak) személyből álló kísérleti csoport (célcsoport) és egy 10 látó személyből álló kontrollcsoport vett részt. Mindannyian a húszas-harmincas éveikben járnak, tehát a fiatal felnőttek életkori kategóriájához tartoznak. A látássérülteknél az életkori tartomány 23-39 év, a kontrollcsoportban 20-25 év volt, a nemekre vetített átlagéletkor a vak nőknél 33,6 év, a vak férfiaknál 29 év, a látó nőknél 23,5, a látó férfiaknál pedig 22,5 év volt. Adatközlőim valamennyien ép értelműek, ép hallásúak, semmilyen pszichés, mentális betegséggel nem küszködnek. A vak csoportban lévők valamennyien születésük óta nem látnak. A nemek mindkét csoportban nagyjából kiegyenlítetten szerepeltek: a látássérülteknél 5 nő, illetve 5 férfi, a látó csoportban pedig 6 nő, illetve 4 férfi szerepelt. Lakóhelyük szerint valamennyien Budapesthez kötődnek (egyetem, föiskola, munkahely). Végzettségüket tekintve adatközlöim egy személy kivételével minimum érettségivel rendelkező személyek.

A felvételek átlagosan 15-20 percet vettek igénybe. A kísérletben négy darab szóasszociációs feladat kapott helyet. Az első feladat szabad szóasszociáció volt: 20 db hívószó esetében meg kellett nevezni az első dolgot, ami eszükbe jut az adott szóról. A szavak négy érzékterület, a hallás, tapintás, szaglás, illetve ízlelés fogalomköréből kerültek ki. A feladat hívószavai a következőek voltak, amelyeket eredeti sorrendben jelzek: puha, zajos, keserü, dohos, kemény, halk, illatos, tompa, édes, hegyes, süvit, sós, áporodott, sima, szagos, savanyú, recseg, iztelen, büdös, kattog. A 20 hívószó szófajok szerinti megoszlása a következő volt: 16 melléknév, 3 ige, 1 igenév.

A második feladatban három hívószó szerepelt, három színnév (piros, sárga, kék). Mindegyik után egy percen keresztül kellett szavakat sorolniuk (nyitott teszt megkötés nélkül). A harmadik feladat szintén szabad szóasszociáció volt: 20 darab szót tartalmazott, amelyek olyan jelenségeket jelölnek, amelyeket főként látás útján lehet befogadni. Ebben a feladatban az alábbi hívószavak szerepeltek a következő sorrendben: sötét, kecses, kontrasztos, borongós, tarka, világos, homályos, fényes, csúnya, borús, szines, nagydarab, csillogó, elhanyagolt, matt, átlátszó, szikrázó, csiricsáré, csinos, szép. Szófajok szerint tehát a megoszlás a következő volt: 18 melléknév, 2 igenév. Az utolsó feladat szintén szabad szóasszociáció volt, 10 darab szót tartalmazott, amelyek a mélység-távolság érzékeléséhez kapcsolódnak. A jelen tanulmány az utolsó feladat eredményeit nem adja közre terjedelmi megfontolásból, annak kifejtése egy másik tanulmány alapját képezheti majd. 
Az asszociátumokat a következő szempontok szerint osztályoztam: a) a szófajmegőrzés-szófajváltás kérdésköre, b) szófajiság, c) gyakoriság (az asszociátumok ismétlődése a csoportokon belül), d) szinonimák és antonimák aránya, e) nincs válasz kategória aránya. A szófajiság kérdéskörének tárgyalásához a besoroló típusú kategóriarendszert vettem alapul (MGr.). A kapott eredményeken az Excel programmal minőségi és mennyiségi elemzéseket végeztem, amelyeket csoportszintre vetítve adok közre; az egyéni jellegzetességek leírása nem része a dolgozatnak.

\section{Eredmények}

3.1. Az 1. szóasszociációs feladat eredményei. A szófajmegőrzés-szófajváltás vizsgálata során a következő eredmények születtek.

A szófajváltás mindkét csoportban nagyobb arányú volt, mint a szófajmegőrzés. A vak csoportban azonban jóval magasabb volt ez a szám, mint a látó kontrollcsoportban, a vakoknál majdnem elérte a 75\%-os arányt, ebböl következően a szófajmegőrzés aránya viszont igen alacsony értékeket mutatott náluk. Szófajváltásra néhány példa a látássérültek csoportjában: halk-troli, szagos-busz, simaasztallap, süvit-zaj, recseg-rádió, kattog-vonat, kattog-buszok. Példák ugyanerre a jelenségre a kontrollcsoportban: halk-toll, sima-kéz, süvít-autó, recseg-ajtó, kattog-agy. Példák szófajmegőrzésre a vakoknál: halk-csendes, illatos-büdös, süvit-eláll, áporodott-igénytelen, sima-érdes, iztelen-izes. Példák erre a stratégiára a kontrollcsoportban: halk-zajos, süvit-sikolt, sima-göcsörtös, iztelen-szagtalan.

A nincs válasz kategória (amikor az adatközlő valamilyen okból kifolyólag nem adott választ) szintén a vakoknál volt nagyobb arányú, a látóknál azonban gyakorlatilag nem fordult elő. Megfigyelhető, hogy a látó csoportban kapott értékek közelebb esnek egymáshoz, mint a vak csoportban kapott számadatok. A pontos számadatokról az 1. táblázat tájékoztat.

\section{1. táblázat}

A két csoport összesített eredményei az 1. szóasszociációs feladatban a szófajmegőrző és szófajváltó válaszszavak tekintetében

\begin{tabular}{|l|c|c|c|}
\hline & Szófajmegőrző párok & Szófajváltó párok & Nincs válasz \\
\hline Vak csoport & $18,5 \%$ & $74,0 \%$ & $7,5 \%$ \\
\hline Látó csoport & $40,0 \%$ & $59,5 \%$ & $0,5 \%$ \\
\hline
\end{tabular}

A szófajiság vizsgálata során a következő megállapításokat lehetett tenni. Az asszociátumok döntő többsége főnév volt mindkét csoportban, a második leggyakoribb előhívott szófaj a melléknév volt, majd elenyésző arányban az igék következnek. A főnevek nagy száma egybecseng a szóasszociációs módszerrel dolgozó korábbi kutatások eredményeivel, melyek szerint általában a szóelőhívások legnagyobb része fónév (LENGYEL 2012).

A fönevek aránya a vak csoportban meghaladta a 70\%-ot, a látó csoportban kisebb volt ennek aránya. A melléknevek a vakoknál azonban kisebb számban jelentkeztek, mint a látóknál, ami egyenesen következik a fentebb a szófajváltásról 
megfogalmazott megállapításokból. Az igék mindkét csoportban $10 \%$ alatt maradtak. Az egyéb kategóriába kerültek a felsorolt szófajkategóriákon kívül előforduló szófajok, mint az igenevek és a határozószavak, valamint ide soroltam a „nincs válasz” kategóriát is. Az adatokból azt lehet kiolvasni, hogy a vakok számos esetben melléknévről főnévre váltottak, hiszen a hívószavak döntő része melléknév volt, asszociátumaik döntő többsége pedig fönév. (Az igék alacsony arányához hozzájárult, hogy a hívószavak között is kis számban szerepeltek). A látó csoport esetében ebben a vonatkozásban is elmondható, hogy a számadataik kiegyenlítettebbek, közelebb esnek egymáshoz, ami az előző táblázat eredményeiből egyenesen következik. A továbbiakban fontos és érdekes kérdésnek tartom annak az okaira rávilágítani, hogy a vak csoportra miért lehet nagyobb mértékben jellemző a szófajváltás, mint a látókra. A pontos eredményekről a 2. táblázat adatai informálnak.

\section{2. táblázat}

A válaszszavak megoszlása a szófajiság tekintetében az 1. szóasszociációs feladatban

\begin{tabular}{|l|c|c|c|c|}
\hline & Főnév & Melléknév & Ige & Egyéb \\
\hline Vak csoport & $71,5 \%$ & $18,0 \%$ & $2,0 \%$ & $8,5 \%$ \\
\hline Látó csoport & $55,0 \%$ & $35,5 \%$ & $5,0 \%$ & $4,5 \%$ \\
\hline
\end{tabular}

A következő kérdéskör az asszociátumok csoportokon belüli, különböző adatközlőknél való azonos előfordulásának a vizsgálata volt.

Azokat a válaszszavakat gyüjtöttem össze, amelyeknek a gyakorisága legalább az egyik csoportban meghaladta az 50\%-ot, vagyis minimum 10-böl 5 személynél előfordultak. Három ilyen példát találni a korpuszban: a szél asszociátum megjelenése a süvít hívószóra, a ropog asszociátum megjelenése a recseg hívószóra, valamint a szagtalan válaszszó az iztelen hívószóra következett. A három példa közül a szél előfordulása mindkét csoportban magas százalékot kapott (1. 3. táblázat), viszont a másik két példa csak a látó csoportban szerepelt nagy arányban. A szél asszociátum megjelenésének a süvit, mint a szél szóláshasonlat lehetett a motivációja, a recseg és a ropog szavak ikerszavakat alkotnak a magyarban, ez lehet a magyarázat a ropog nagy arányára. Az íztelen és a szagtalan szavak összepárosításának oka pedig a hasonló hangzás lehetett, de ahogy a táblázatból is látható, a látó csoportban jelent meg több esetben, a válaszadók felénél (1. 3. táblázat).

A további átfedéseket a két csoport között az azonos válaszszavak tekintetében az alábbiakban mutatom be. (Az első adat mindig a vak csoportra, a második a kontrollcsoportra vonatkozik).

A halk hívószóra a vakoknál és a látóknál is az antonim hangos volt a leggyakoribb asszociátum (20-20\%), valamint egy, illetve két esetben előfordult a csend (a vakoknál csönd hangalakkal) is. Az illatos hívószóra a virág asszociátum aktiválása volt a leggyakoribb (30\%, ill. 40\%), a tompá-ra az éles (20\%, ill. 30\%), az édes-re a keserü (20-20\%), a hegyes-re a tü (30\%, ill. 20\%), a süvit-re a szél $(60 \%$, ill. $80 \%)$, a sós-ra a mogyoró $(10 \%$, ill. $20 \%)$, az áporodott-ra a levegó 
(10\%, ill 20\%), a simá-ra az érdes (20\%, ill. 30\%), a szagos-ra az illatos $(10 \%$, ill. $40 \%$ ), a savanyú-ra a cukor (20, ill. $40 \%)$, a recseg-re a ropog $(30 \%$, ill. $60 \%)$, az iztelen-re az étel (30\%, ill. 10\%), valamint a szagtalan (10\%, ill. 50\%), a büdös-re az illatos $(10 \%$, ill. 30\%), a kattog-ra a gép $(10 \%$, ill. 10\%). Ezekből az adatokból megfigyelhetö, hogy a kontrollcsoporton belül gyakoribb az azonos válaszszavak aktiválása, mint a vak csoportban. A felsorolt példák között 15-böl 10 esetben náluk volt több megegyező asszociátum.

Ebben a feladatban nem volt egyetlen olyan hívószó sem, amelyre a két csoportban előhívott asszociátumok sorában ne lett volna ismétlődés.

\section{3. táblázat}

50\%-ot meghaladó elöfordulási gyakoriságú válaszszavak az 1. szóasszociációs feladatban (zárójelben a hívószavak szerepelnek)

\begin{tabular}{|l|c|c|c|}
\hline & $\begin{array}{c}\text { szél } \\
\text { (süvít) }\end{array}$ & $\begin{array}{c}\text { ropog } \\
\text { (recseg) }\end{array}$ & $\begin{array}{c}\text { szagtalan } \\
\text { (iztelen) }\end{array}$ \\
\hline Vak csoport & $60 \%$ & $30 \%$ & $10 \%$ \\
\hline Látó csoport & $80 \%$ & $60 \%$ & $50 \%$ \\
\hline
\end{tabular}

A következőkben a szinonimák (a SzinSz. alapján) és antonimák előfordulási arányát vizsgálom.

Összességében elmondható, hogy a szinonimák és antonimák aktiválása a két csoportban $15 \%$ körül vagy az alatt volt. A vak csoportban a szinonimák aránya igen elenyésző volt, $4 \%$, a látóknál ez a szám $12 \%$. Az antonimák aktiválási gyakorisága közelebb esett egymáshoz a két csoportban: a vakoknál 11, a látóknál 15\%-ot ért el. A vakoknál kapott százalékérték a szinonimák előhívásában ugyancsak összhangban áll a fentiekben leírtakkal: erre a csoportra volt nagyobb mértékben jellemző a szófajváltás, ebből egyenesen következik, hogy náluk a szinonimák aránya is alacsonyabb lesz.

A „nincs válasz” kategória a vak csoportban volt nagyobb arányú, ahol a következő hívószavak okoztak nehézséget az adatközlőknek: tompa, sima, áporodott, recseg.

További megfigyelés, hogy a közlekedési eszközök, jármúvek, közlekedési viszonyok fogalomkörébe tartozó szavak a vakoknál nagyobb arányban jelentkeztek a hangok, hanghatások szemantikai köréhez tartozó hívószavak után. 17 esetben találtam rá példát, a látó csoportban mindössze két esetben. Példák az ebbe a fogalomkörbe tartozó válaszszavakra a vak csoportból: motor ( $2 \mathrm{db})$, busz (2 db), 7-es busz, buszok, troli, járda, város, út, utca, padló, vonat, állomás, irányjelzö, forgalom, Hungária körút.

Ennek az lehet a magyarázata, hogy a látássérültek életében a közlekedés egy kritikus pont, máshogy tájékozódnak, mint a látók, valamint a közlekedési eszközök zaját eröteljesebben érzékelik, a hang alapján azonosítják be ezeket.

A legjellemzőbb tematikus kategóriák emellett a használati tárgyak, étel-ital megnevezése, növénynevek, valamint a természeti jelenségeket jelölő szavak voltak. 
A fonetikai hasonlóság igen csekély arányban mutatkozott motivációs tényezőként: a vakoknál egyáltalán nem, a látóknál is mindösszesen két esetben találni rá példát a vizsgált korpuszban.

3.2. A 2. szóasszociációs feladat eredményei. Ebben a feladatban a piros, a sárga és a kék hívószó szerepelt ebben a sorrendben, s a feladat az volt, hogy megkötés nélkül mindegyik hívószó után egy percen keresztül folyamatosan szavakat aktiváljanak.

Az előhívott szavak számában jelentős különbség mutatkozott a két csoport között. A piros hívószóra a vak csoportban 94 asszociátum, a látóknál 198 érkezett, vagyis utóbbi több mint a kétszerese a vakok teljesítményének. A vakok 60\%-a 10-nél kevesebb számú szót tudott előhívni hívószavanként, és csupán ketten lépték át a 10 szavas határt. Ezzel szemben a látó csoportban valamennyien 10 szó felett aktiváltak szavakat, 80\%-uk 15 és 20 szó között teljesített, valamint két személy (20\%) asszociációinak a száma átlépte a 30-at.

A sárga hívószó esetében 76 db előhívott szó volt a vak csoportban, a látóknál több mint ennek kétszerese, 153 darab szó volt összesen. A vak csoport $80 \%$-a kevesebb, mint 10 szót aktivált. Ezzel szemben a látóknál egy ilyen személy sem volt: 90\%-uk 10 és 20 darab szó között hívott elő szavakat, egy személy pedig több mint húszat.

A kék hívószó esetében a látók által aktivált szavak összege 160 darab volt, míg a vakoknál ezzel szemben mindössze 86 darab érkezett, vagyis átlagosan: $8,6<16 \mathrm{db}$ szó/fö volt jellemzö, tehát a látók majdnem dupla annyi szót vagy szerkezetet, kifejezést tudtak előhívni ugyanannyi idő alatt. A vak csoport 70\%-a kevesebb, mint 10 darab szót tudott kiejteni, ebből hárman kevesebb, mint 5 (!) szót aktiváltak (4-4-2) (lásd 1. ábra).

1. ábra

A 2. feladat során aktivált szavak száma részfeladatonként (db)

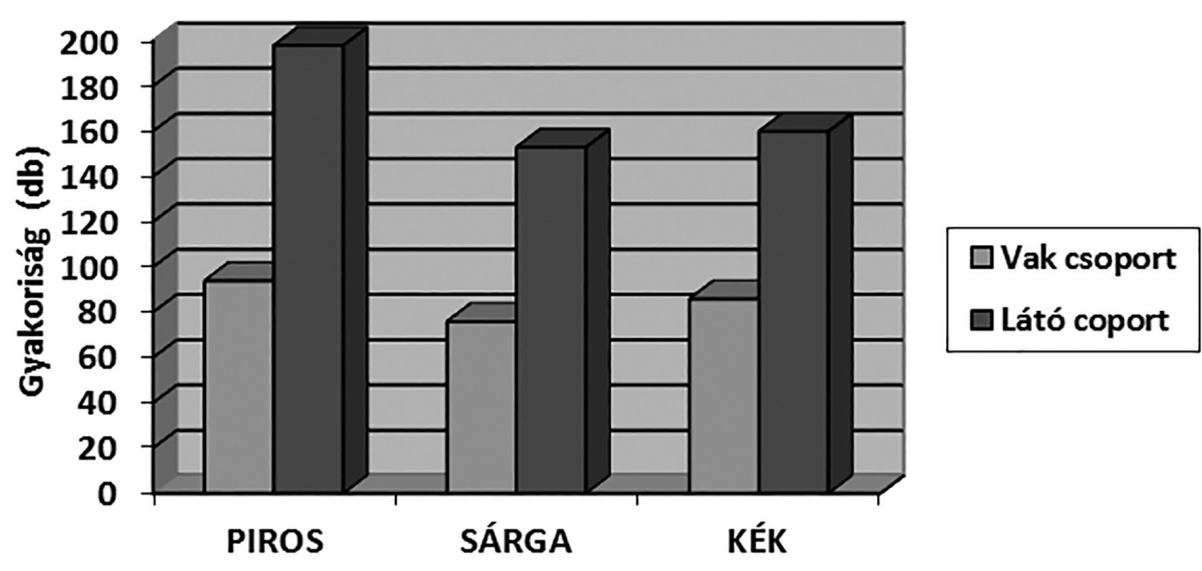


Az asszociátumok között a legjellemzőbb tematikus kategóriák a használati tárgyak, a ruhadarabok, a természeti jelenségek és a növénynevek voltak. Az előhívott szavak szófaj szerinti döntő többsége mindkét csoportban a főnév, ezt követte a melléknév kategóriája. Inflexiós szavakra elenyésző számú példát találni a korpuszban. Több esetben is elöfordult azonban, hogy az előhívott szavak paradigmatikus sort képeztek: sapka, dzseki, pulóver; paprika, retek, áfonya, szőlö; sampon, tusfürdö, testápoló, szappan, fogkrém, fogkefe, fogselyem; melegitö, cipö, sál, kabát, ruha.

Érdemes megemlíteni azt a jelenséget, hogy a vakoknál a piros, a sárga és a kék szó mint szóelem többször jelentkezett az elöhívott szavakban, mint a látóknál. Ennek magyarázata az lehet, hogy ezt használták egyfajta „kapaszkodóként” az előhívásban, hiszen esetükben ehhez a három színnévhez nem kapcsolódik érzékleti tartalom. A sárga szóelem a vak csoportban több mint a válaszadók felénél megjelent (60\%), a látóknál viszont csak 30\%-ban. A kék szóelem a vakoknál 30\%-ban, a látóknál csak 1 személynél (10\%) fordult elő. A piros szóelem egyaránt 10-10\%-os gyakoriságú volt, ami feltehetően annak tudható be, hogy ez a morféma nem alkot a magyarban gyakori összetételi tagot.

Feltűnő volt, hogy a szín asszociátum megjelenése is a vakokat jellemezte nagyobb arányban. Vagyis náluk volt az megfigyelhető, hogy egyből megpróbálták kategóriába sorolni, és ezáltal értelmezni az elhangzott hívószót. Az 1. részfeladatban (piros) náluk 60\%-ban, míg a látóknál csupán 10\%-ban jelentkezett az említett asszociátum. A sárga, illetve kék hívószó esetében is elmondható, hogy ez a megoldás a vak csoportot jellemezte inkább (20\%-30\%), a látóknál elenyésző számban jelentkezett (0\%-10\%).

3.3. A 3. szóasszociációs feladat eredményei. Az asszociátumokat ebben az esetben is az 1. feladat során alkalmazott szempontok szerint osztályoztam, hogy össze lehessen vetni az eredményeket: a) a szófajmegőrzés-szófajváltás, b) szófajiság, c) gyakoriság (az asszociátumok ismétlődése a csoportokon belül), d) szinonimák és antonimák aránya, e) „nincs válasz” kategória aránya.

A szófajmegőrzés-szófajváltás tekintetében az 1 . feladathoz hasonló eredmény született, hiszen a vak csoportban volt nagyobb arányú a hajlandóság a szófajváltásra. Néhány példa a vak csoportban előforduló szófajváltásra: fényes-csillag, elhanyagolt-külsö, csinos-hölgy, átlátszó-ruha, matt-tányér, szikrázó-napfény, csillogó-viztükör. Példák ugyanerre a jelenségre a kontrollcsoportból: fényes-ablak, elhanyagolt-kert, csinos-ember, csúnya-apukám, átlátszó-tejüveg. Példák szófajmegörzésre a vak csoportból: fényes-ékes, csúnya-szép, szines-gazdag, matt-fénytelen, átlátszó-homályos. Példák erre a jelenségre a kontrollcsoportból: fényes-sötét, csúnya-szép, szines-tarka, átlátszó-áttetszö.

További hasonlóság az 1-es feladathoz képest, hogy szintén a vakoknál fordult elő többször, hogy nem adtak reakciót a hívószóra, a látóknál viszont egy esetben sem volt erre példa. Az 1. és a 3. feladat összevetésében elmondható, hogy nincsen jelentős különbség sem a szófajmegőrzés-szófajváltás, sem a „nincs válasz” kategória kérdésében. (A 3. feladat pontos számadatait a 4. táblázat szemlélteti.) 


\section{4. táblázat}

A két csoport összesített eredményei a 3. szóasszociációs feladatban a szófajmegőrző és szófajváltó válaszszavak tekintetében

\begin{tabular}{|l|c|c|c|}
\hline & Szófajmegőrző párok & Szófajváltó párok & Nincs válasz \\
\hline Vak csoport & $24,0 \%$ & $72,0 \%$ & $4,0 \%$ \\
\hline Látó csoport & $39,5 \%$ & $60,5 \%$ & $0,0 \%$ \\
\hline
\end{tabular}

A szófajiság vonatkozásában az látható az adatokból, hogy a két csoport kiegyenlítetten teljesített, és nem olyan kiugróan magas a vak csoportban aktivált főnevek száma, mint az 1. feladat során volt. Igék aktiválására nem volt példa, amiben nagy szerepe lehetett annak, hogy a hívószavak között sem volt ige. Az egyéb kategória tartalmazza a kevés számú igenevet és határozószót, ami előfordult, valamint a „nincs válasz” kategóriát (1. 5. táblázat).

\section{5. táblázat}

A válaszszavak megoszlása a szófajiság tekintetében a 3. szóasszociációs feladatban

\begin{tabular}{|l|c|c|c|c|}
\hline & Főnév & Melléknév & Ige & Egyéb \\
\hline Vak csoport & $67,0 \%$ & $23,0 \%$ & $0,0 \%$ & $10,0 \%$ \\
\hline Látó csoport & $63,5 \%$ & $33,0 \%$ & $0,0 \%$ & $6,0 \%$ \\
\hline
\end{tabular}

A következő kérdéskör az asszociátumok gyakoriságának meghatározása volt az egyes csoportokon belül és a csoportok között. Az azonos csoporton belül $50 \%$-ot elérö gyakoriságú válaszszavak száma 5 darab volt, valamint az idő, illetve a napsütés szó aránya meghaladta vagy az egyik, vagy a másik csoportban ezt az százalékértéket (1. 6. táblázat).

A két csoport közötti azonos válaszszavaknak az előfordulását mutató további átfedéseket az alábbiakban részletezem, az egynél több esetben jelentkező asszociátumok kiemelésével. (A százalékértékek között az első adat mindig a vak csoportra, a második mindig a kontrollcsoportra vonatkozik.)

A sötét hívószóra az éjszaka (40\%, ill. 20\%) válaszszó volt a leggyakoribb, a kontrasztos-ra a kép (20-20\%), a borongós-ra az idö (60\%, ill. 10\%), a tarká-ra a barka (40\%, ill. 20\%), a világos-ra a sötét (30\%, ill. 60\%), a homályos-ra a kép (10\%, ill. 20\%), fényes-re a sötét (20\%, ill. 30\%), a csúnyá-ra a szép $(20 \%$, ill. $40 \%$ ), a nagydarab-ra az ember (20\%, ill. 30\%), a matt-ra a sakk $(20 \%$,. ill. 10\%), az átlátszó-ra az üveg (50\%, ill. 40\%), a szikrázó-ra a napsütés (60\%, ill. 30\%), a csinos-ra a lány $(30 \%$, ill. 10\%), a szép-re a csúnya $(10 \%$, ill. 30\%). Itt nem ismétlődik meg az a minta, amely az 1. feladatban jelentkezett, hogy a kontrollcsoport résztvevőire lenne nagyobb mértékben jellemző az azonos asszociátumok aktiválása: a 14 kiemelt példa felében a vakoknál, másik felében a látóknál volt nagyobb arányú az ismétlődés. 
A vak csoportban három olyan hívószó (kecses, homályos, csillogó) is volt ebben a feladatban, amelynek elhangzása után a 10 adatközlő 10 különböző szót aktivált. A kontrollcsoportban pedig két ilyen hívószó volt, az elhanyagolt és a csiricsáré. Valamint további eltérés, hogy az 1. feladattal szemben ebben a feladatban volt olyan hívószó, amelynek az asszociátumai között nem volt ismétlődés a két csoport között. Ez a hívószó a színes, amely tehát a legjobban megosztotta a válaszadás tekintetében a kísérleti személyeket.

\section{6. táblázat}

50\%-ot meghaladó előfordulási gyakoriságú asszociátumok a 3. szóasszociációs feladatban (a zárójelben a hívószavak szerepelnek).

\begin{tabular}{|l|c|c|c|c|}
\hline & $\begin{array}{c}\text { világos } \\
\text { (sötét) }\end{array}$ & $\begin{array}{c}\text { idö } \\
\text { (borongós) }\end{array}$ & $\begin{array}{c}\text { üveg } \\
\text { (átlátszó) }\end{array}$ & $\begin{array}{c}\text { napsütés } \\
\text { (szikrázó) }\end{array}$ \\
\hline Vak csoport & $10 \%$ & $60 \%$ & $50 \%$ & $60 \%$ \\
\hline Látó csoport & $50 \%$ & $10 \%$ & $40 \%$ & $30 \%$ \\
\hline
\end{tabular}

A szinonimák (SzinSz. alapján) nagyjából egyenlő arányban voltak jellemzőek a két csoport válaszaiban $(5,5 \%)$, az antonimák száma valamennyivel nagyobb eltérést mutatott: a vakoknál a válaszszavak 9,5\%-ában, a látóknál pedig 14,5\%-ban jelentkeztek. A legjellemzőbb tematikus kategóriák a használati tárgyak, ruhadarabok nevei, valamint az állatnevek voltak. A szópárok közötti fonetikai hasonlóság aránya ebben a feladatban is nagyon alacsony volt.

4. Összegzés, következtetések. 1. számú hipotézisem az volt, hogy a vakok és látók asszociációi nagyobb eltérést mutatnak a látás által felfogható jelenségeket jelölő hívószavak esetében, mint a nem a látásérzékeléssel összefüggő szavak esetén. Ezt a hipotézist a kapott eredményekkel összevetve a következő megállapítások tehetők.

A 3. feladat eredményei alapján, a szófajmegőrzés-szófajváltás kérdésében - hasonlóan az 1. feladathoz - a vakoknál volt jellemzőbb a szófajváltás, és általában melléknévről főnévre váltottak. Tehát ez hasonlóságot jelent a két feladat között. Különbség viszont, hogy az 1 . feladat során a vak csoportban kevesebb volt azoknak a hívószavaknak a száma, amelyek esetében azonos asszociátumok jelentek meg különböző személyeknél. Tehát ebben a feladatban a kontrollcsoport eredményei voltak homogénebbek, a vakoké heterogénebbek. Ezzel szemben a 3. feladatban az azonos asszociátumok megjelenése kiegyenlítettebb a két csoportban.

A szófaji kategóriák kérdését tekintve lényeges különbség a számadatok között nem keletkezett, hiszen mindkét csoportban a fönevek voltak túlsúlyban, ezt követte a melléknevek száma, a többi szófaj aránya viszont elenyésző volt. Különbség azonban mind az 1., mind a 3. feladat vonatkozásában, hogy a vakoknál volt gyakoribb az, hogy nem érkezett válasz az elhangzott hívószó után. A szinonimák és antonimák számában nem tapasztaltam lényeges eltérést.

A 2. szóasszociációs feladat (nyitott teszt) során mutatkoztak további eltérések a két csoport között. A vártnak megfelelően a célcsoport által aktivált válasz- 
szavak száma lényegesen kisebb, mint a kontrollcsoport ugyanezen számadata. A tematikus kategóriákban alapvető eltérést nem lehet megfigyelni. Ami különbséget jelentett, hogy a hívószavak az asszociátum szóelemeként gyakrabban jelentkeztek a vakoknál, valamint a hívószavak kategóriába sorolása is a vak csoportra volt inkább jellemző. 1. számú hipotézisemet mindezek alapján részben teljesültnek minősítem.

2. számú hipotézisem az volt, hogy azon hívószavak, amelyek olyan jelenségeket jelölnek, amelyek a többi érzékszervünk által is felfoghatók, nagyobb hasonlóságot mutatnak a vakok a látókhoz az asszociációk tekintetében. Ez a hipotézisem nem teljesült, hiszen az 1. és a 3. szóasszociációs feladat eredményei nem mutatnak lényegi különbséget a fentebb kiemelt szempontokat figyelembe véve.

Az eredményekből arra lehet következtetni, hogy a vakok és látók mentális lexikona bizonyos tekintetben eltérő reprezentációkat tárol. A válasz azokra a kérdésekre, hogy ezek vajon hogyan müködnek, pontosan hogyan fogalmazható meg az eltérés, és mekkora ennek mértéke, további kutatások lefolytatásával lehetne elérni.

5. Kitekintés. A jelen kutatáshoz közvetlenül kapcsolódó célok lehetnek például a fonetikai (hangzási), grammatikai, valamint a szemantikai alapú motiváció arányának megállapítása a hívószavak és a válaszszavak viszonyában; az idiomatikus kifejezések számarányának megállapítása; a toldalékolt válaszszavak, ezen belül az inflexiós és derivációs szavak előfordulásának vizsgálata; a leggyakoribb válaszszavak hosszúságának elemzése. Mindezek mellett a reakcióidők mérése is fontos adalékul szolgálhat.

Kulcsszók: mentális lexikon, látássérültek, szóasszociáció, szabad szóaszszociáció, szúkített szóasszociáció, nyitott teszt, lexikális hozzáférés.

\section{Hivatkozott irodalom}

Bedny, Maria - Pascual-Leone, Alvaro - Dravida, Swethasri - SaXe, Rebecca 2012. A sensitive period for language in the visual cortex: Distinct patterns of plasticity in congenitally versus late blind adults. Brain and Language 122: 162-170. http://dx.doi.org/10.1016/j.bandl.2011.10.005

Bottini, Roberto - CRePAldi, DAVIDE - CASASANTO, DANIEL - CROllen, Virgine Collignon, Olivier 2015. Space and time in the sighted and blind. Cognition 141: 67-72. http://dx.doi.org/10.1016/j.cognition.2015.04.004

CZIBERE CSILlA - SzILÁGYI VERA szerk. 2006: Ajánlások vak és aliglátó gyermekek, tanulók kompetencia alapú fejlesztéséhez. Életpálya-épités. SuliNova Közoktatásfejlesztési és Pedagógus-továbbképzési Kht., Budapest.

Dietrich, Susanne - Hertrich, IngO - ACKERMAnN, Hermann 2015. Network Modeling for Functional Magnetic Resonance Imaging (fMRI) Signals during Ultra-Fast Speech Comprehension in Late-Blind Listeners. PLoS ONE 10/7: 1-21. http://[-] dx.doi.org/10.1371/journal.pone.0132196

GELD, RENATA 2014. Investigating meaning construal in the language of the blind: A cognitive linguistic perspective. Suvremena Lingvistika 40: 27-56. 
GÓSY MÁRIA 2000. Az életkor hatása a mentális lexikon müködésére. Magyar Nyelvőr 124: 410-423.

Gósy MÁrIa 2005. Pszicholingvisztika. Osiris Kiadó. Budapest.

GÓSY MÁRIA - KOVÁCS MAGDOLNA 2001. A mentális lexikon a szóasszociációk tükrében. Magyar Nyelvőr 125: 330-354.

GougouX, FrédériC - LePore, Franco - LASSONde, MARYSE - Voss, PATRICE - ZATORRE, RoBERT J. 2004. Pitch discrimination in the early blind. Nature, Volume 430, Number 6997. 309. http://dx.doi.org/10.1038/430309a

Hertrich, Ingo - Dietrich, Susanne - Ackermann, Hermann 2013. How can audiovisual pathways enhance the temporal resolution of time-compressed speech in blind subjects? Frontiers in Psychology 2013/4: 1-12. http://dx.doi.org/10.3389/[-] fpsyg.2013.00530

HughdAhl, KenNETH - EK, MARIA - TAKIO, FIIA et alii 2004. Blind individuals show enhanced perceptual and attentional sensitivity for identification of speech sounds. Cognitive Brain Research 19: 28-32. http://dx.doi.org/10.1016/j.cogbrainres.2003.10.015

KANJLIA, SHIPRA - LANE, CONNOR - FEIGENSON, LiSA - BEDNY, MARINA 2016. Absence of visual experience modifies the neural basis of numerical thinking. Proceedings of the National Academy of Science 113: 11172-11177. http://dx.doi.org/10.1073/[-] pnas. 1524982113

KOVÁCS LÁSZLÓ 2013. Fogalmi rendszerek és lexikai hálózatok a mentális lexikonban. Segédkönyvek a nyelvészet tanulmányozásához 150. Tinta Könyvkiadó, Budapest.

LENGYel Zsolt 2012. Szóról szóra. Szóasszociációs vizsgálatok. Gondolat Kiadó, Budapest.

LUKÁCS ÁGNES 2014. Szótanulás. In: PlÉH CSABA - LUKÁCS ÁGNES szerk., Pszicholingvisztika. Magyar pszicholingvisztikai kézikönyv 1-2. Akadémiai Kiadó, Budapest. 1: 521-545.

LuKÁCs ÁGNeS - PléH CSABA - KAS BenCE - ThuMA ORsolyA 2014. A szavak mentális reprezentációja és az alaktani feldolgozás. In: PLÉH CSABA - LUKÁCS ÁGNES szerk., Pszicholingvisztika. Magyar pszicholingvisztikai kézikönyv 1-2. Akadémiai Kiadó, Budapest. 1: 167-239.

MGr. = KESZLER BORBÁLA szerk., Magyar grammatika Nemzeti Tankönyvkiadó. Budapest, 2006.

NEUBERGER TILDA 2008. A szókincs fejlődése óvodáskorban. Anyanyelv-pedagógia 1/34. http://www.anyanyelv-pedagogia.hu/cikkek.php?id=86

PAJOR EMESE 2010. Látássérülés. Bevezető ismeretek. Eötvös Loránd Tudományegyetem Bárczi Gusztáv Gyógypedagógiai Kar, Budapest.

PÁLHEGYI FERENC 1981. A látás nélkül meghódított világ. Fejezetek a vakok pszichológiájához. Vakok és Gyengénlátók Országos Szövetsége, Budapest.

PARASZKAY SÁRA 2007. Közelről nézve. A gyengénlátó gyermek. Gyengénlátók Általános Iskolája, Egységes Gyógypedagógiai Módszertani Intézménye és Diákotthona, Budapest.

SCHINAZI, Victor R. - THRASH, TYLER - CHEBAT, DANIEL-RoberT 2016. Spatial navigation by congenitally blind individuals. Wiley Interdisciplinary Reviews: Cognitive Science: $37-58$. http://dx.doi.org/10.1002/wcs.1375 
SzinSz. = O. NAGY GÁBOR - RUZSICZKY ÉVA, Magyar szinonimaszótár. Akadémiai Kiadó, Budapest, 1978.

\section{Investigating the mental lexicon of blind people by word-association tasks}

In this paper my aim is to find out what the main differences or similarities are between blind people and sighted people regarding their mental lexicon, and what representations there are in the mental lexicon of blind people about words and things that they cannot sense. I used various types of word association tasks to look into this question. 10 congenitally blind and 10 sighted people took part in this investigation. My hypothesis was that the associations of blind people would differ from the associations of participants in the control group for words that refer to things that we can only perceive by sight. I found both differences and similarities between the two groups. Blind participants activated more nouns than sighted participants both in the first task and in the third task, and in the first task the difference was very salient. The number of the associated words was far fewer in the second task in the blind group. The reason for that could be that this task contained three colour names, red, yellow and blue, and blind people cannot perceive colours. The number of synonyms and antonyms was similar.

Keywords: mental lexicon, sight-impaired people, blindness, word-association test, fluency test, lexical access, cognition.

HANTÓ RÉKA

Eötvös Loránd Tudományegyetem MTA Nyelvtudományi Intézet 